University of Nebraska - Lincoln

DigitalCommons@University of Nebraska - Lincoln

Faculty Papers and Publications in Animal

Science

Animal Science Department

1990

\title{
Efficacy of the Urea Dilution Technique in Estimating Empty Body Composition of Pigs Weighing 50 Kilograms
}

\author{
L. I. Chiba \\ University of Nebraska-Lincoln
}

A. J. Lewis

University of Nebraska-Lincoln, alewis2@unl.edu

E. R. Peo, Jr.

University of Nebraska-Lincoln

Follow this and additional works at: https://digitalcommons.unl.edu/animalscifacpub

Part of the Animal Sciences Commons

Chiba, L. I.; Lewis, A. J.; and Peo, Jr., E. R., "Efficacy of the Urea Dilution Technique in Estimating Empty Body Composition of Pigs Weighing 50 Kilograms" (1990). Faculty Papers and Publications in Animal Science. 687.

https://digitalcommons.unl.edu/animalscifacpub/687

This Article is brought to you for free and open access by the Animal Science Department at DigitalCommons@University of Nebraska - Lincoln. It has been accepted for inclusion in Faculty Papers and Publications in Animal Science by an authorized administrator of DigitalCommons@University of Nebraska - Lincoln. 


\title{
EFFICACY OF THE UREA DILUTION TECHNIQUE IN ESTIMATING EMPTY BODY COMPOSITION OF PIGS WEIGHING 50 KILOGRAMS ${ }^{1,2}$
}

\author{
L. I. Chiba, A. J. Lewis ${ }^{3}$ and E. R. Peo, Jr. \\ University of Nebraska ${ }^{4}$, Lincoln 68583-0908 \\ ABSTRACT
}

\begin{abstract}
The efficacy of the urea dilution technique in estimating the empty body composition of pigs weighing $50 \mathrm{~kg}$ was evaluated in three trials using 17 contemporary (Large White $\times$ Landrace $\times$ Hampshire $\times$ Duroc) and 8 Nebraska Gene Pool $\times$ contemporary pigs. Blood samples were collected via ear catheter before infusion $(-60,-30$ and $0 \mathrm{~min}$ ) and at various times ( 3 to 90 min) after urea infusion ( $2.16 \mathrm{mmol} / \mathrm{kg}$ live $\mathrm{BW})$, and analyzed for plasma urea. Backfat thickness of live pigs from the contemporary line was measured ultrasonically. Pigs then were killed by euthanasic injection, and total bodies (with gastrointestinal contents removed) were analyzed for water, protein and fat. In Trials 1 and 2 , there were linear relationships $(P<.001)$ between chemically determined body water and fat and between body water and protein. Urea space was related $(P<.05)$ to empty body components with few exceptions, but regression coefficients for urea space in Trial 3 were different from those of Trials 1 and 2 . Inclusion of additional independent variables with urea space improved estimation of empty body components. Although backfat alone did not estimate empty body components (except fat) as well as urea space alone, the addition of other common independent variables resulted in better estimates using backfat than urea space. The results of this experiment indicate that the urea dilution technique can be used to estimate the body composition of growing pigs. However, the accuracy obtained depended on the population of pigs being investigated and was no greater than the accuracy with appropriate equations based on backfat.
\end{abstract}

(Key Words: Growth, Pigs, Body Composition, Urea Dilution.)

J. Anim. Sci. $1990.68: 372-383$

\section{Introduction}

Water dilution techniques using isotopes such as deuterium and tritium oxides have been used to estimate body composition in pigs (Houseman et al., 1973; Shields et al., 1983a; Rudolph et al.,

\footnotetext{
${ }^{1}$ Joumal Series No. 8853, Agric. Res. Div., Univ. of Nebraska. Research reported was conducted under Project 13-052.

${ }^{2}$ The technical assistance of R. L. Carlson, R. M. Diedrichsen, J. D. Hancock, J. D. Kopf and J. L. Kovar (Univ. of Nebraska) and B. Larsen (U.S. Meat Anim. Res. Center) is gratefully acknowledged.

${ }^{3}$ To whom reprint requests should be addressed.

${ }^{4}$ Dept. of Anim. Sci.

Received February 27, 1989.

Accepted June 16, 1989.
}

1988), sheep (Meissner, 1976) and cattle (Meissner et al., 1980). However, the costs and complexity of analytical procedures and the difficulties associated with the use of radioactive isotopes (e.g., tritium) limit their use in large animals.

San Pietro and Rittenberg (1953) indicated that urea appeared to be a suitable substance to estimate body water. Unea costs much less than the hydrogen isotopes, and the analytical procedures for measuring urea are relatively simple. Since Preston and Kock (1973) reported that urea space was highly correlated with empty body water and fat in cattle, a number of investigators have demonstrated that urea dilution can be used to estimate the body components of ruminants (Kock and Preston, 1979; Meissner et al., 1980; Bartle et al., 1983; Hammond et al., 1984). The 
TABLE 1. COMPOSITION OF DIETS

\begin{tabular}{|c|c|c|c|c|c|c|c|}
\hline \multirow[b]{2}{*}{ Item } & \multicolumn{7}{|c|}{ Trial $^{\mathrm{a}}$} \\
\hline & $1 \& 2$ & $1 \& 2$ & $1 \& 2$ & 3 & $1,2 \& 3$ & 3 & 3 \\
\hline & & & & $\%$ & & & \\
\hline \multicolumn{8}{|l|}{ Ingredients } \\
\hline Corn & 11.98 & 11.98 & 15.98 & 18.77 & 21.91 & 25.57 & 29.83 \\
\hline Soybean meal ( $44 \%$ CP) & 14.37 & 14.37 & 19.17 & 22.53 & 26.28 & 30.67 & 35.78 \\
\hline Tallow & & 15.00 & 15.00 & 5.00 & 5.00 & 5.00 & 5.00 \\
\hline Com starch & 52.50 & 46.87 & 38.65 & 41.20 & 34.75 & 27.24 & 18.49 \\
\hline Sand & 12.35 & 2.98 & 2.54 & 3.93 & 3.59 & 3.18 & 2.71 \\
\hline Dextrose & 5.00 & 5.00 & 5.00 & 5.00 & 5.00 & 5.00 & 5.00 \\
\hline Dicalcium phosphate & 2.83 & 2.83 & 2.60 & 2.44 & 2.26 & 2.05 & 1.80 \\
\hline Limestone & .22 & .22 & .31 & .38 & .45 & .54 & .64 \\
\hline Salt (iodized) & .50 & .50 & .50 & .50 & .50 & .50 & .50 \\
\hline Trace mineral mix & .10 & .10 & .10 & .10 & .10 & .10 & .10 \\
\hline Vitamin mix $x^{c}$ & .10 & .10 & .10 & .10 & .10 & .10 & .10 \\
\hline Selenium premix ${ }^{d}$ & .05 & .05 & .05 & .05 & .05 & .05 & .05 \\
\hline \multicolumn{8}{|l|}{ Calculated analysis } \\
\hline $\mathrm{DE}, \mathrm{Mcal} / \mathrm{kg}$ & $3 . \infty 0$ & 4.00 & 4.00 & 3.50 & 3.50 & 3.50 & 3.50 \\
\hline $\mathrm{CP}, \%$ & 7.38 & 7.38 & 9.84 & 11.56 & 13.49 & 15.75 & 18.37 \\
\hline Lysine, \% & .45 & .45 & .60 & .71 & .82 & .96 & 1.12 \\
\hline $\mathrm{Ca}, \%$ & .75 & .75 & .75 & .75 & .75 & .75 & .75 \\
\hline $\mathrm{P}, \%$ & .65 & .65 & .65 & .65 & .65 & .65 & .65 \\
\hline
\end{tabular}

"In addition to the seven diets shown, a com-soybean meal-based diet (16\% CP) was fed to one gilt in Trial 3.

${ }^{b}$ Provided the following ( $\mathrm{mg} / \mathrm{kg}$ of complete diet): $\mathrm{Zn}, 75 ; \mathrm{Fe}, 87.5 ; \mathrm{Mn}, 30 ; \mathrm{Cu}, 8.75 ; \mathrm{I}, .75$.

'Provided the following per kilogram of complete diet: vitamin A, 2,755 IU; vitamin $\mathrm{D}_{3}, 275 \mathrm{IU}$; vitamin E, $11 \mathrm{IU}$; menadione sodium bisulfite, $1.1 \mathrm{mg}$; riboflavin, $2.8 \mathrm{mg}$; d-pantothenic acid, $9.9 \mathrm{mg}$; niacin, $16.5 \mathrm{mg}$; choline chloride, $275 \mathrm{mg}$; vitamin $B_{12}, 8.3 \mu g$; ethoxyquin, $2.2 \mathrm{mg}$.

${ }^{\mathrm{d}}$ Provided $.10 \mathrm{mg} / \mathrm{kg}$ of complete diet.

only data with swine are the reports of Stansbury et al. (1985) and Mitchell and Steele (1987). Both groups indicated that urea dilution may have potential in the estimation of body composition of growing-finishing pigs.

The purpose of the present research was to evaluate the urea dilution technique in pigs weighing $50 \mathrm{~kg}$. Results were compared with estimates based on backfat thickness.

\section{Experimental Procedure}

Animals, Diets and Facilities. Two genetic lines of crossbred pigs, Nebraska Gene Poolcross (Gene Pool sows $\times$ Large White $\times$ Landrace $\times$ Duroc boars) for Trial 1 (eight pigs) and contemporary (Large White $\times$ Landrace $\times$ Duroc $\times$ Hampshire) for Trials 2 (eight pigs) and 3 (nine pigs), were used in the experiment. Pigs, averag-

\footnotetext{
${ }^{3}$ Lean-Meater, Renco Corp., Minneapolis, MN.

${ }^{6}$ Bolab Incorporated, Lake Havasu City, AZ.
}

ing 22.3, 21.6 and $20.4 \mathrm{~kg}$ for Trials 1, 2 and 3, respectively, were assigned at random within sex (four gilts and four barrows) to four diets. The purpose of using diets with various compositions (Table 1) was to produce pigs with different body compositions. The diets met or exceeded requirements (NRC, 1988) for all nutrients except amino acids in some diets. An additional diet (com-soybean meal-based, containing $16 \% \mathrm{CP}$ ) was fed to one gilt in Trial 3. Pigs had ad libitum access to feed and water.

Pigs were housed individually in rooms with continuous fluorescent lighting maintained at $21^{\circ} \mathrm{C}$ (Trials 1 and 2) or 21 to $24^{\circ} \mathrm{C}$ (Trial 3). In Trials 2 and 3 , when pigs weighed approximately $50 \mathrm{~kg}$, backfat was measured with an ultrasonic instrument $\mathrm{t}^{5} 4$ to $5 \mathrm{~cm}$ from the midline on the right side at the third rib, last rib and last lumbar vertebra. The mean of the three positions was used in regression analyses. Urea space was estimated when pigs weighed approximately $50 \mathrm{~kg}$.

Urea Infusion and Blood Sample Collection. A catheter (vinyl i.v. tubing, size V/5) ${ }^{6}$ was intro- 


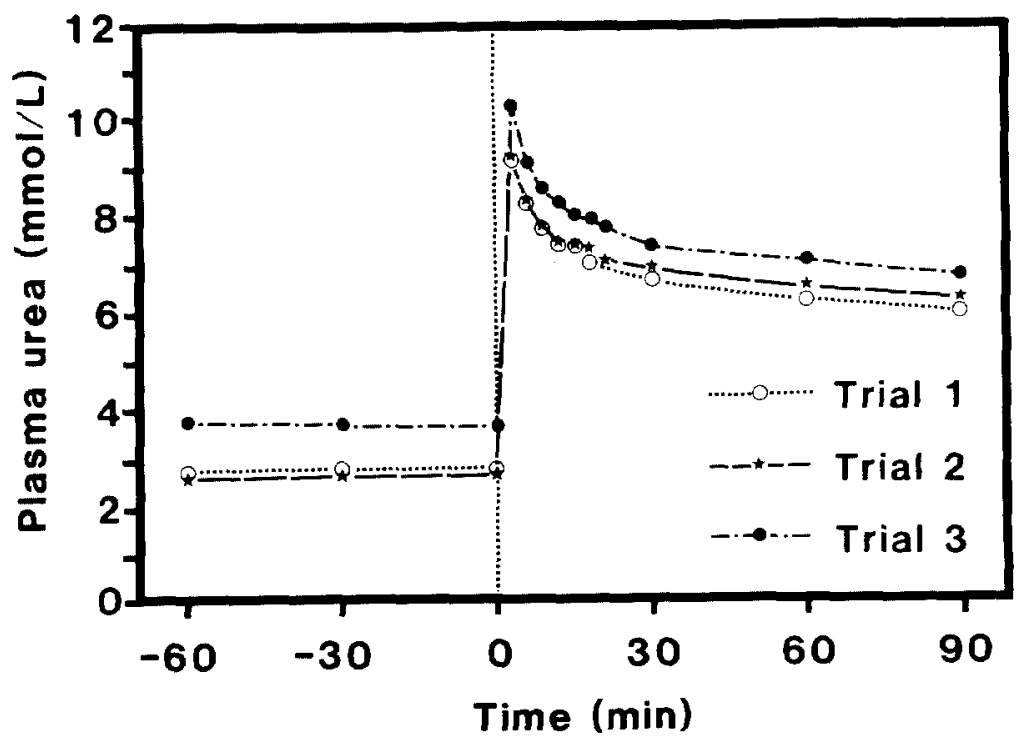

Figure 1. Mean dilution curves of plasma urea in pigs weighing $50 \mathrm{~kg}$. Blood samples were taken at $-60,-30,0,3$, $6,9,12,15,18,21$ (except in Trial 1), 30,60 and $90 \mathrm{~min}$. The range of initial plasma urea concentrations was 1.58 to $5.03 \mathrm{mmol}$ iter. Interassay coefficients of variation for plasma urea analysis were $2.11,2.20$ and $3.84 \%$ for Trials 1,2 and 3 , respectively.

duced into an ear vein via a disposable 14-gauge needle $(2.5 \mathrm{~cm}$ long). Approximately 25 to $30 \mathrm{~cm}$ of tubing was inserted and the catheter was filled with $\mathrm{Na}$ citrate solution ( $35 \mathrm{~g}$ /liter) to prevent blood clotting. The catheter was held on the top of shoulders using elastic tape and tag cement. Two pigs were catheterized via vena cava instead of ear vein. One pig in Trial 1 died as a result of vena cava catheterization and consequently no urea space data were obtained. This pig was, however, analyzed for chemical body composition.

Pigs were allowed to acclimate to metabolism crates for at least $1 \mathrm{~d}$ before urea infusion. Pigs were fasted ovemight, and water was withheld 30 min prior to urea infusion and thenceforth. Urea solution (130 g urea/liter $\mathrm{NaCl}$ [9 $\mathrm{g} /$ /iter] solution) was prepared daily and filtered through a $.2-\mu \mathrm{m}$ filter. The specific gravity of the urea solution also was determined. A syringe containing urea solution was weighed before and after each infusion to determine the amount of urea infused.

\footnotetext{
${ }^{7}$ Euthanasia-6, Veterinary Laboratories, Inc., Lenexa, KS and Na pentobarbital, Anthony Products Co., Arcadia, CA.

${ }^{8}$ Model 1109, Weiler and Co., Whitewater, WI.
}

Pigs were weighed and three blood samples were taken before urea infusion $(-60,-30$ and 0 $\mathrm{min})$. Urea solution ( $2.16 \mathrm{mmol}$ urea/ $\mathrm{kg}$ live $\mathrm{BW}$ ) was infused over a $2.5-\mathrm{min}$ period, and the catheter was flushed with $5 \mathrm{ml}$ of $\mathrm{NaCl}$ solution. Blood samples were taken at various times after the end of urea infusion (see Figure 1). All blood samples were transferred immediately to heparinized tubes. Catheters were filled with $\mathrm{Na}$ citrate solution between samplings to prevent blood clotting. Plasma was separated by centrifugation, and an aliquot was stored at $-20^{\circ} \mathrm{C}$ until it was analyzed for urea by the automated method of Marsh et al. (1965). All samples from each pig were analyzed as a single run using the same set of standards.

Chemical Analysis of Empty Body. After the last blood samples were collected, pigs were killed by infusion of $\mathrm{Na}$ pentobarbital ${ }^{7}$, and the contents of gastrointestinal tracts were removed. The total empty body of each pig, sealed in a plastic bag, was weighed and stored at $-20^{\circ} \mathrm{C}$. The carcasses subsequently were reweighed to determine any moisture loss during the freezing process and then were ground three times in a grinder ${ }^{8}$ equipped with a 6.4- $\mathrm{mm}$ diameter screen. Triplicate samples (500 to $800 \mathrm{~g}$ each) were placed in plastic containers, weighed and stored at $-20^{\circ} \mathrm{C}$. Samples were reweighed and 
ground at least two more times with a meat grinder ${ }^{9}$ using a 3-mm plate. Triplicate samples were analyzed in duplicate (six samples per pig) for $D M, C P(N \times 6.25)$ and crude fat. Dry matter was determined according to the method of AOAC (1984). Nitrogen was determined with a Kjeltec apparatus ${ }^{10}$ using procedures delineated by AOAC (1984). Samples were freeze-dried and analyzed for crude fat using an 8-h extraction with purified ethyl ether in a Goldfisch apparatus $^{11}$ following procedures described by AOAC (1984).

Estimation of Urea Space. The Y-intercept (zero-time) of plasma urea concentration for each pig was estimated by semilog regression using plasma urea concentrations from the straight portion of the dilution curve (determined by subjective evaluation and linear regression). For most pigs this represented samples obtained at 18,21 , 30,60 and $90 \mathrm{~min}$ post-infusion. Urea space (liters or $\mathrm{kg}$ ) was calculated by dividing the quantity of urea infused (mmol) by the difference between the mean plasma urea concentrations prior to infusion (mmol/liter) and the estimated Y-intercept value (mmol/liter). Urea space also was expressed as a percentage of live and of empty BW.

Statistical Analysis. Data were subjected to statistical analyses described by SAS (1985) using individual pigs as the experimental unit. Simple regressions were developed to describe the relationships among chemically determined empty body water, protein and fat. Similarly, simple regressions of the empty body chemical components on live BW, urea space and backfat thickness were developed. Forward stepwise regression analyses then were performed with various independent variables. Multiple regressions subsequently were developed using the GLM procedure with the selected variables. All regressions were developed within each trial and for the three trials combined (except for regressions involving backfat thickness, which was not measured in Trial 1). The homogeneity of regression coefficients among the three trials and two sexes was tested using trial and sex as class variables.

\footnotetext{
${ }^{9}$ Toledo Chopper, Model 5120-0-009, Toledo Scale Co., Toledo, $\mathrm{OH}$.

10 Tecator, Hoganas, Sweden.

${ }^{11}$ Labconco Model 1787, Laboratory Construction Co., Kansas City, MO.
}

\section{Results and Discussion}

Dilution Curves of Plasma Urea. The mean dilution curves of plasma urea in pigs weighing approximately $50 \mathrm{~kg}$ are presented in Figure 1 . Plasma urea concentrations were lower in Trials 1 and 2 than in Trial 3, probably because a higher$\mathrm{CP}$ diet was fed in Trial 3. However, the relative differences before and after urea infusion were similar in all three trials. Pre-infusion (initial) plasma urea concentrations remained constant across sampling times $(-60,-30$ and $0 \mathrm{~min})$ for each pig. After urea infusion, there was a sharp increase in plasma urea concentration. This was followed by a rapid decrease during the first 3 to $12 \mathrm{~min}$ post-infusion. Urea appeared to achieve equilibrium with body water by approximately $15 \mathrm{~min}$ after the infusion. However, equilibration times differed from one pig to another (the range was approximately 9 to $21 \mathrm{~min}$ ). Meissner (1976) reported similar findings in sheep. Plasma urea concentrations decreased continuously, but more gradually, after reaching apparent equilibrium, probably due to renal clearance and(or) transfer of urea into the gastrointestinal tract (Bartle and Preston, 1986; Trenkle, 1986). Because of variation in the equilibration time among the pigs and theoretical considerations (Meissner, 1976), urea space was determined by extrapolating the straight portion of the curve back to zero-time (the Y-intercept) instead of using one particular time period, as suggested for cattle by Preston and Kock (1973).

Body Components, Age and Urea Space. The least squares means and ranges of live and empty BW, age, chemically determined empty body components, urea space and backfat thickness in pigs weighing $50 \mathrm{~kg}$ are presented in Table 2 . Although the empty (digesta-free) BW of pigs in Trial 2 was lower than in the two other trials, in general the live BW (fasted ovemight) and empty BW were similar for the three trials. The age at which body composition was determined was different among the trials $(P<.05)$ and probably was due to the differences in genetic lines and the types of diets used in the three trials. Differences observed in the empty body components and water and protein (percentage of fat-free empty body) among the trials probably were due to the genetic lines, ages of pigs and(or) the types of diets used in the trials. On a fat-free basis, barrows contained more water ( 76.7 vs $76.3 \%$ ) and less protein (19.9 vs $20.3 \%)$ than gilts did $(P<.05)$. The effect of sex on empty body water on a fat-free basis has been reported by Garrett et 


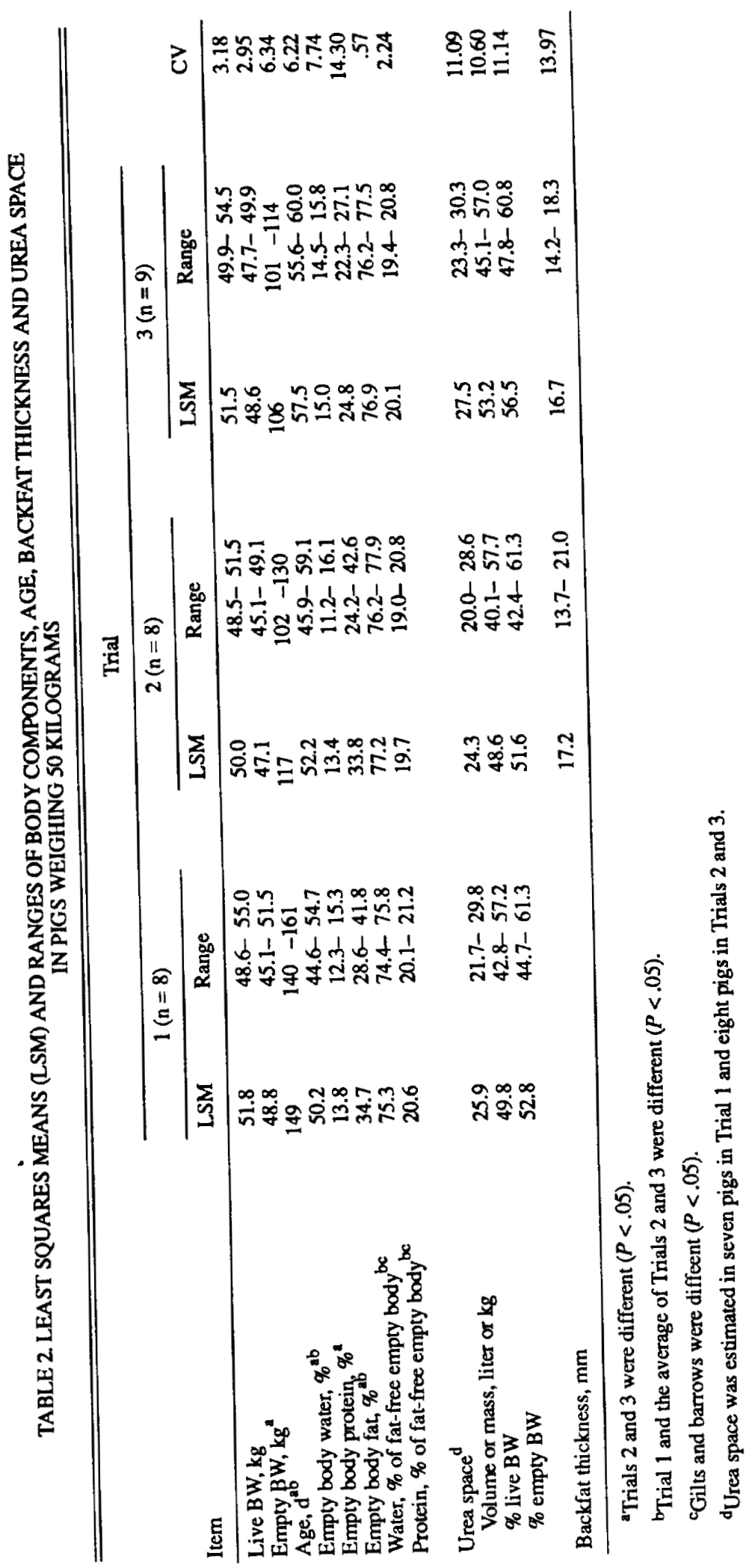


TABLE 3. RELATIONSHIPS BETWEEN LIVE BODY WEIGHT AND EMPTY BODY WEIGHT, AND CHEMICALLY DETERMINED EMPTY BODY WATER, PROTEIN AND FAT IN PIGS WEIGHING 50 KILOGRAMS

\begin{tabular}{|c|c|c|c|c|c|c|}
\hline \multirow[b]{2}{*}{ Dependent variable and trial } & \multicolumn{3}{|c|}{ Regression coefficients ${ }^{a}$} & \multirow[b]{2}{*}{$P^{\mathrm{b}}$} & \multirow[b]{2}{*}{$\mathbf{S E}^{\mathrm{c}}$} & \multirow[b]{2}{*}{$\mathbf{R}^{2}$} \\
\hline & $\mathrm{b}_{0}$ & $\begin{array}{l}\mathrm{b}_{1} \\
\text { (LBW) }\end{array}$ & $\begin{array}{l}\mathrm{b}_{2} \\
\left(\mathrm{EBH}_{2} \mathrm{O}\right)\end{array}$ & & & \\
\hline \multicolumn{7}{|l|}{ Empty BW, kgd } \\
\hline 1 & 1.6982 & .9084 & & .001 & .77 & .87 \\
\hline 2 & -1.0987 & .9643 & & .001 & .50 & .89 \\
\hline 3 & 24.9047 & .4603 & & .001 & .31 & .84 \\
\hline \multicolumn{7}{|l|}{ Empty body protein, \% } \\
\hline 1 & -1.0711 & & .2953 & .001 & .36 & .90 \\
\hline 2 & -3.9692 & & .3322 & .001 & .31 & .97 \\
\hline 3 & 5.5847 & & .1640 & .128 & .37 & .30 \\
\hline Combined & .3884 & & .2562 & .001 & .54 & .83 \\
\hline \multicolumn{7}{|l|}{ Empty body fat, \% } \\
\hline 1 & 100.2066 & & -1.3051 & .001 & 1.05 & .95 \\
\hline 2 & 103.0527 & & -1.3259 & .001 & .48 & .99 \\
\hline 3 & 90.5886 & & -1.1457 & .001 & .45 & .93 \\
\hline Combined & 104.4470 & & -1.3769 & .001 & 1.14 & .96 \\
\hline
\end{tabular}

a Model was $\mathrm{Y}=\mathrm{b}_{0}+\mathrm{b}_{1} \mathrm{X}_{1}$, where $\mathrm{Y}=\operatorname{empty} \mathrm{BW}(\mathrm{kg})$ and $\mathrm{X}_{1}=$ live $\mathrm{BW}(\mathrm{LBW} ; \mathrm{kg})$ or $\mathrm{Y}=\mathrm{b}_{0}+\mathrm{b}_{2} \mathrm{X}_{2}$, where $\mathrm{Y}=$ empty body components (\%) and $\mathrm{X}_{2}=$ empty body water $\left(\mathrm{EBH}_{2} \mathrm{O} ; \%\right)$.

${ }^{b} P$-value of the regression coefficient for independent variable.

'Standard error of estimate for the regression model.

${ }^{d}$ Regression coefficient for live BW in Trial 3 was different from Trials 1 and 2 , thus the combined analysis is not presented.

al. (1971) for cattle (73.5 vs $73.0 \%$ for steers and heifers, respectively) and by Shebaita (1977) for mice ( 73.5 vs $73.9 \%$ for males and females, respectively).

An initial evaluation of relationships between urea space and the observed and predicted empty body components revealed that data from one pig in Trial 3 deviated $(P<.05)$ from the overall fit of the model. This pig had been re-catheterized during the morning of urea infusion and its pattern of plasma urea concentrations was erratic. Values from this pig were excluded from the regression analyses.

Although there was no statistical difference $(P>.05)$, urea space tended to be higher for pigs in Trial 3 than for those in Trials 1 and 2. On an empty BW basis, urea space overestimated empty body water by approximately $5 \%$ in Trial 1 , but slightly underestimated it in Trials 2 and 3 . The reason for this difference is not apparent. Preston and Kock (1973), Meissner et al. (1980) and Rule et al. (1986) have reported that urea space underestimated empty body water in cattle. Rule et al. (1986) suggested that underestimation may be a typical feature of the urea dilution technique.
Relationships Among Body Components. Regression coefficients for the independent variables in gilts and barrows were homogeneous; thus, common regressions were derived to describe the relationships among body components. Relationships between live BW and empty BW, and empty body water, protein and fat are presented in Table 3. As expected, empty BW was related to live BW in each trial $\left(\mathrm{R}^{2}=.84\right.$ to .89 ; $P<.001$ ). The regression coefficient in Trial 3 appeared to diverge from those of Trials 1 and 2; therefore, a combined regression is not presented. Shields et al. (1983a) and Ferrell and Cornelius (1984) reported that empty BW can be predicted accurately from live BW $\left(\mathrm{R}^{2}=.99\right)$. The lower coefficients of determination obtained in the present experiment probably were caused by the narrow ranges of the $B W$ and the use of diets with diverse compositions.

There was a strong relationship $(P<.001)$ between chemically determined body water and protein in Trials 1 and 2, but not in Trial 3. Body water was inversely related $(P<.001)$ to body fat in all three trials. The regression coefficients obtained in this experiment (slopes and intercepts) 
TABLE 4. RELATIONSHIPS BETWEEN UREA SPACE OR LIVE BODY WEIGHT AND CHEMICALLY DETERMINED EMPTY BODY COMPONENTS IN PIGS WEIGHING 50 KILOGRAMS

\begin{tabular}{|c|c|c|c|c|c|c|}
\hline \multirow[b]{2}{*}{ Dependent variable and trial } & \multicolumn{3}{|c|}{ Regression coefficients ${ }^{\mathrm{ab}}$} & \multirow[b]{2}{*}{$P^{c}$} & \multirow[b]{2}{*}{$\mathrm{SE}^{\mathrm{d}}$} & \multirow[b]{2}{*}{$\mathrm{R}^{2}$} \\
\hline & $b_{0}$ & $\begin{array}{l}b_{1} \\
\text { (US) }\end{array}$ & $\begin{array}{l}\mathrm{b}_{2} \\
(\mathrm{LBW})\end{array}$ & & & \\
\hline \\
\hline 1 & 6.3077 & .7080 & \multirow{3}{*}{.8673} & .007 & 1.11 & .80 \\
\hline & -20.3536 & & & .020 & 1.38 & .69 \\
\hline \multirow[t]{2}{*}{2} & 11.7819 & .5270 & & .025 & 1.40 & .59 \\
\hline & 15.9711 & & \multirow[t]{2}{*}{.1719} & .793 & 2.19 & .01 \\
\hline \multirow[t]{2}{*}{3} & 19.9134 & .2911 & & .008 & .49 & .72 \\
\hline & 9.1819 & & \multirow{2}{*}{$\begin{array}{l}.3628 \\
.6456\end{array}$} & .118 & .75 & .36 \\
\hline Combined & -7.2657 & & & .018 & 2.11 & .24 \\
\hline \multicolumn{7}{|l|}{ Empty body protein, $\mathrm{kg}$} \\
\hline 1 & 1.7819 & .1931 & \multirow[b]{2}{*}{.2223} & .010 & .34 & .76 \\
\hline \multirow{2}{*}{2} & -4.7472 & & & .046 & $\begin{array}{r}.45 \\
49\end{array}$ & .58 \\
\hline & $\begin{array}{l}1.8148 \\
2.8177\end{array}$ & .1847 & \multirow{2}{*}{.0696} & $\begin{array}{l}.024 \\
.760\end{array}$ & $\begin{array}{l}.49 \\
.76\end{array}$ & $\begin{array}{l}.60 \\
.02\end{array}$ \\
\hline \multirow[t]{2}{*}{3} & 6.3233 & .0339 & & .223 & .17 & .24 \\
\hline & 3.3702 & & .0752 & .111 & .15 & .37 \\
\hline Combined & -3.7078 & & .2050 & .007 & .57 & .30 \\
\hline \multicolumn{7}{|l|}{ Empty body fat, $\mathrm{kg}$} \\
\hline 1 & $\begin{array}{l}30.8854 \\
23.9661\end{array}$ & -.5416 & \multirow{2}{*}{-.1368} & .107 & 1.95 & .43 \\
\hline \multirow{2}{*}{2} & 37.9527 & -.9068 & & $\begin{array}{l}.787 \\
.005\end{array}$ & $\begin{array}{l}2.57 \\
1.64\end{array}$ & $\begin{array}{l}.02 \\
.76\end{array}$ \\
\hline & -19.6433 & & \multirow[t]{2}{*}{.7116} & .465 & 3.19 & .09 \\
\hline \multirow[t]{2}{*}{3} & 17.0966 & -.1831 & & .165 & .77 & .29 \\
\hline & 5.9543 & & .1183 & .640 & .90 & .04 \\
\hline Combined & 18.0008 & & -.0611 & .871 & 3.13 & .00 \\
\hline
\end{tabular}

a Regression coefficients for urea space among the trials were not homogeneous for all three dependent variables, thus the combined analyses are not presented.

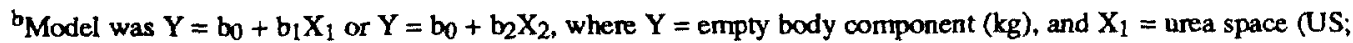
$\mathrm{kg})$ and $\mathrm{X}_{2}=$ live $\mathrm{BW}(\mathrm{LBW} ; \mathrm{kg})$.

c $P$-value of the regression coefficient for independent variable.

${ }^{d}$ Standard error of estimate for the regression model.

were similar to those reported by Reid et al. (1968) and Ferrell and Comelius (1984) in pigs, Arnold et al. (1985) in cattle and Bartle et al. (1988) in sheep. As Ferrell and Comelius (1984) indicated, the accuracy of estimating body composition using any water dilution technique can be no better than that obtained from using actual empty body water. The results of this experiment with pigs confirm that if the empty body water can be estimated accurately, then empty body protein and fat can be predicted accurately.

Simple Regression Analysis. The relationships between urea space or live BW and chemically determined empty body components are presented in Table 4. Using live BW as the independent variable resulted in much less satisfactory estimates of empty body composition of pigs than using urea space, with one exception (protein in Trial 3). In contrast to the present findings, BW has been shown to be highly correlated with body composition in sheep (Reid et al., 1968; Bartle et al., 1988), cattle (Hammond et al., 1984, 1988) and pigs (Shields et al., 1983b; Ferrell and Cornelius, 1984).

Regression coefficients for urea space in Trial 3 were different from those of Trials 1 and 2 $(P<.05)$. Although the relationships between empty body water and urea space $\left(R^{2}=.59\right.$ to .80 ; $\mathrm{SE}=.49$ to $1.40 \mathrm{~kg}$ ) were not so strong as those reported by Meissner (1976) in sheep $\left(\mathrm{R}^{2}=.93\right.$ to $.95 ; \mathrm{SE}=1.68$ to $1.97 \mathrm{~kg}$ ) and Hammond et al. (1984) in cattle $\left(\mathrm{R}^{2}=.89\right.$ to $.92 ; \mathrm{SE}=8.4$ to 9.0 
$\mathrm{kg}$ ), they were comparable to those of Stansbury et al. (1985) in pigs $\left(R^{2}=.53\right)$, Mitchell and Steele (1987) in pigs $\left(\mathrm{R}^{2}=.60 ; \mathrm{SE}=1.52 \mathrm{~kg}\right)$ and Lawrence et al. (1986) in horses $\left(R^{2}=.50\right)$. The relationship of urea space with empty body protein and fat was rather weak in Trial 3, possibly due to the narrow ranges of the body composition. By excluding one observation from Trial 1 that deviated greatly from the rest in empty body fat content, the $\mathrm{R}^{2}$ for estimating body fat from urea space was increased from .43 to .85 . Coefficients of determination for estimating empty body protein and fat obtained in our experiment were comparable to those reported by Mitchell and Steele (1987) for fat in 50- and $90-\mathrm{kg}$ pigs $\left(\mathrm{R}^{2}=.41\right.$ and .21 , respectively; $\mathrm{SE}=4.57$ and $5.61 \%$, respectively) and Stansbury et al. (1985) for protein and fat $\left(\mathrm{R}^{2}=.52\right.$ and .58 , respectively) in pigs weighing 54 to $101 \mathrm{~kg}$. These results indicate that urea space can be used to estimate body composition of growing pigs.

Multiple Regression Analysis. The results of stepwise regression analyses revealed that including other independent variables improved the prediction models. Thus, multiple regression analyses were conducted using initial plasma urea concentration and empty $\mathrm{BW}$ as common variables with urea space to predict empty body water, protein and fat in all three trials. A fourth independent variable, age or sex, also was in. cluded when these variables improved the prediction models.

The results of multiple regression analyses are presented in Table 5. Inclusion of additional independent variables improved the accuracy of estimating empty body composition from urea space in all three trials. The regression coefficients for Trial 3 appeared to be dissimilar to those for Trials 1 and 2 as they were in the simple regression equations (Table 4). However, the number of experimental units was inadequate for full analysis of homogeneity. Limited analysis did not reveal significant differences between slopes. Therefore, regressions were developed for each trial separately and for the pooled data. Alternative computations in which initial plasma urea concentration was replaced by dietary protein level yielded regression equations that were similar to those reported in Table 5.

Changes in concentration of urea may alter the rate of urea clearance and, consequently, the estimation of empty body water (Trenkle, 1986). This may explain why the inclusion of plasma urea concentration, prior to urea infusion, improved the prediction of empty body water. Kock and Preston (1979) and Bartle et al. (1983) observed some improvement in estimation of body composition by including initial plasma urea concentration with urea space in cattle. Similarly, prediction equations were improved by the inclusion of body mass, using urea space in cattle (Meissner et al., 1980; Hammond et al., 1988; Rule et al., 1986) and using deuterium oxide space in pigs (Ferrell and Cornelius, 1984). Furthermore, in view of questions regarding the possible effects of age (Reid et al., 1955; Rattray et al., 1974; Shields et al., 1983b) and sex (Garrett et al., 1971; Shebaita, 1977) on the "water concept" proposed by Pace and Rathbun (1945), these variables were included in the regression equations to improve the prediction of body composition.

The relationships between empty body components and urea space or backfat thickness and other independent variables in contemporary pigs are presented in Table 6. To compare the two methods of estimating the empty body composition the same independent variables (empty BW and age) were included in both sets of equations. The polynomial and interaction terms for independent variables also were included in the regression analyses, and those terms that did not contribute to the models were subsequently excluded. Initial concentration of plasma urea, which contributed substantially to improve prediction models based on urea space, was not included in these models. Although backfat thickness alone did not predict the empty body composition (except fat) as well as urea space alone, the inclusion of the polynomial term of backfat thickness, empty BW and age resulted in better estimates of body composition, indicated by higher coefficients of determination and lower standard errors of estimates.

Rule et al. (1986) evaluated the urea dilution equations for estimating empty body water in cattle (Preston and Kock, 1973; Meissner et al., 1980; Hammond et al., 1984). Some regression equations appeared to overestimate empty body water. However, they indicated that, overall, the urea dilution technique was valid on the basis of statistical evaluation of parameters determined by regression analyses of the estimates on chemically determined values. Likewise, Bartle et al. (1987) concluded, after conducting a validation study, that urea space was a valid estimator of body composition in growing-finishing cattle. Based on experiments with lambs, Bartle et al. (1988) concluded that "the proportion of variation in body composition accounted for by urea 
CHIBA ET AL.

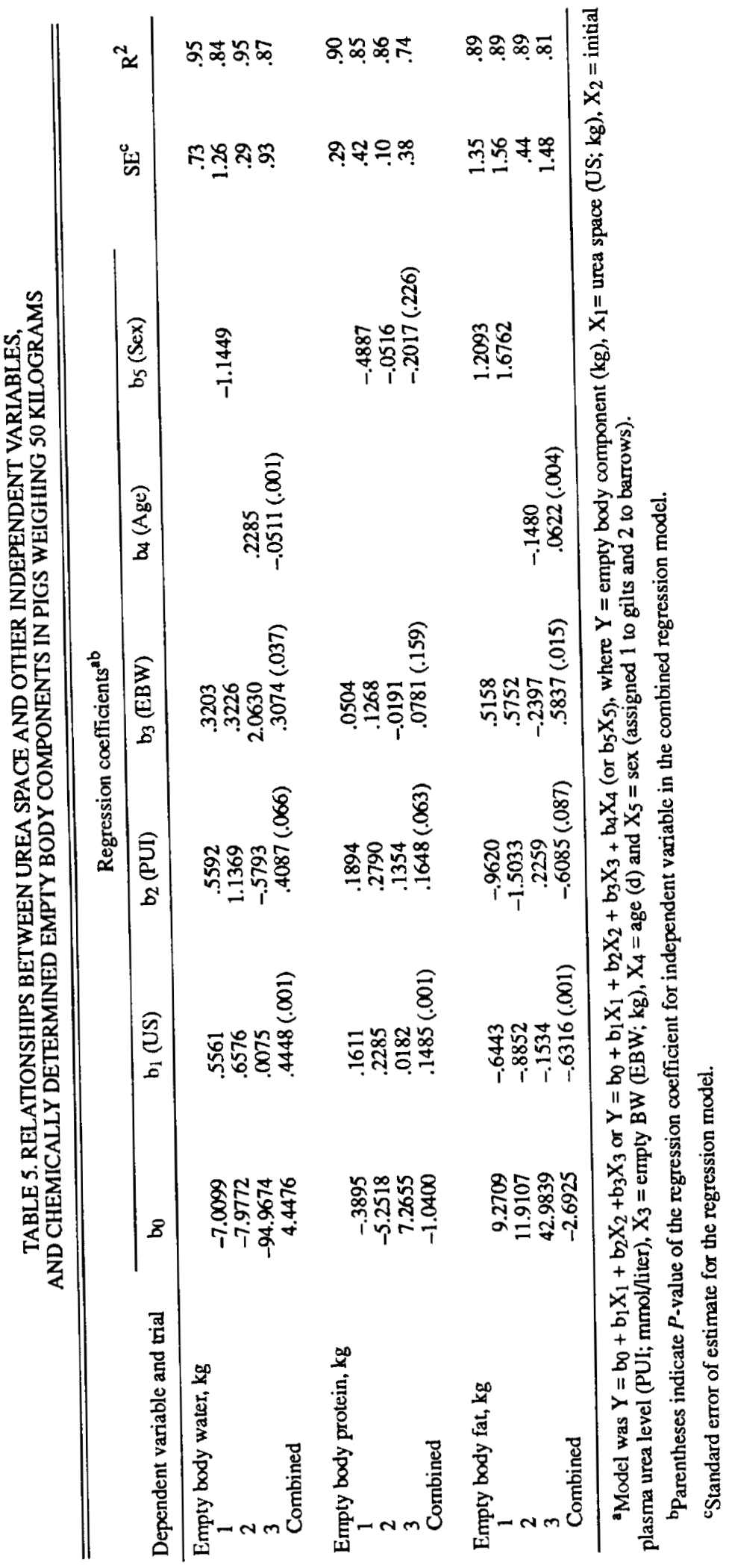




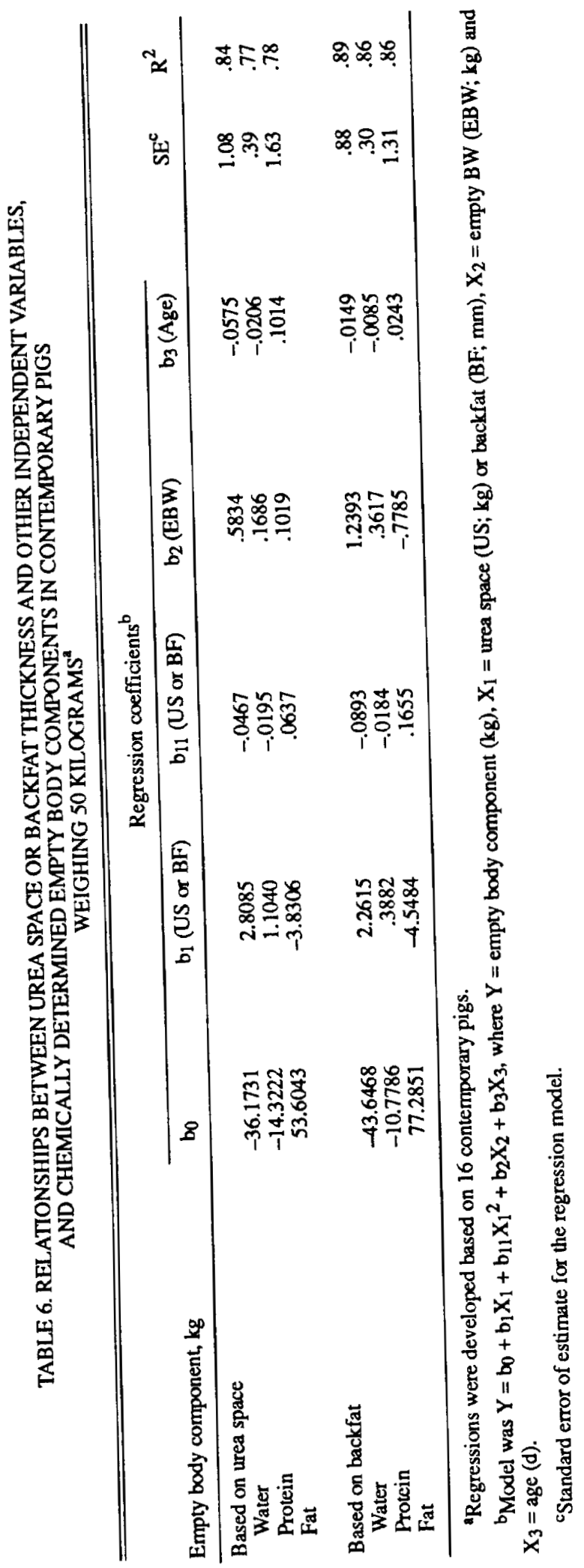


space was not satisfactory" and that empty body water could be predicted as well by live weight as by urea space. The results of the present experiment indicate that the urea dilution technique can be used to estimate the empty body composition of growing pigs. However, there were differences between the results obtained in the three trials. Appropriate equations based on backfat were as precise as those based on urea space.

\section{Implications}

The urea dilution technique can be used to estimate the empty body composition of pigs weighing approximately $50 \mathrm{~kg}$. The low costs and minimal technical requirements associated with plasma urea analysis make the urea dilution technique an attractive alternative to dilution techniques using isotopes of hydrogen or to comparative slaughter and dissection methods. Differences in regression equations between different experiments indicate that there may not be one set of regression equations that is universally applicable to pigs of $50 \mathrm{~kg}$. Appropriate equations based on backfat thickness were as accurate as those based on urea dilution for predicting body composition.

\section{Uterature Clied}

AOAC. 1984. Official Methods of Analysis (14th Ed.). Association of Official Analytical Chemists, Washington, DC.

Amold, R. N., E. J. Hentges and A. Trenkle. 1985. Evaluation of the use of deuterium oxide dilution techniques for determination of body composition of beef steers. J. Anim. Sci. 60:1188.

Bartle, S. J., S. W. Kock, R. L. Preston, T. L. Wheeler and G. W. Davis. 1987. Validation of urea dilution to estimate in vivo body composition in cattle. J. Anim. Sci. 64:1024.

Bartle, S. J., J. R. Males and R. L. Preston. 1983. Evaluation of urea dilution as an estimator of body composition in mature cows. J. Anim. Sci. 56:410.

Bartle, S. J. and R. L. Preston. 1986. Plasma, rumen and urine pools in urea dilution determination of body composition in cattle. J. Anim. Sci. 63:77.

Bartle, S. J., O. A. Turgeon, Jr., R. L. Preston and D. R. Brink 1988. Procedural and mathematical considerations in urea dilution estimation of body composition in lambs. J. Anim Sci. 66:1920.

Ferrell, C. L. and S. G. Cornelius. 1984. Estimation of body composition of pigs. J. Anim. Sci. 58:903.

Garrett, W. N., W. C. Rollins, M. Tanaka and N. Hinman. 1971. Empty body and carcass composition of cattle. J. Anim Sci. 33:194 (Abstr.).

Hammond, A. C., T. S. Rumsey and G. L. Haaland. 1984. Estimation of empty body water in steers by urea dilution. Growth 48:29.

Hammond, A. C., T. S. Rumsey and G. L. Haaland. 1988. Prediction of empty body components in steers by urea dilution. J. Anim. Sci. 66:354.
Houseman, R. A., I. McDonald and K. Pennie. 1973. The measurement of total body water in living pigs by deuterium oxide dilution and its relation to body composition. Br. J. Nutr. 30:149.

Kock, S. W. and R. L. Preston. 1979. Estimation of bovine carcass composition by the urea dilution technique. J. Anim. Sci. 48:319.

Lawrence, L. M., R. A. Kane, P. A. Miller, S. R. Reece and C. Hartman. 1986. Urea space determination and body composition in horses. J. Anim. Sci. 63(Suppl. 1):233 (Abstr.).

Marsh, W. H., B. Fingerhut and H. Miller. 1965. Automated and manual direct methods for the determination of blood urea. Clin. Chem. 11:624.

Meissner, H. H. 1976. Urea space versus tritiated water space as an in vivo predictor of body water and body fat. South Afr. J. Anim. Sci. 6:171.

Meissner, H. H., J. H. van Staden and E. Pretorius. 1980. In vivo estimation of body composition in cattle with tritium and urea dilution. I. Accuracy of prediction equations for the whole body. South Afr. J. Anim. Sci. 10:165.

Mitchell, A. D. and N. C. Steele. 1987. Comparisons of urea space, deuterium oxide space and body composition in growing pigs. Growth 51:118.

NRC. 1988. Nutrient Requirements of Swine (9th Ed.). National Academy Press, Washington, DC.

Pace, N. and E. N. Rathbun. 1945. Studies on body composition. III. The body water and chemically combined nitrogen content in relation to fat content. J. Biol. Chem. 158:685.

Preston, R. L. and S. W. Kock. 1973. In vivo prediction of body cormposition in cattle from urea space measurements. Proc. Soc. Exp. Biol. Med. 143:1057.

Rattray, P. V., W. N. Garrett, N. Hinman and N. E. East. 1974. Effects of level of nutrition, pregnancy and age on the composition of the wool-free ingesta-free body and carcass of sheep. J. Anim. Sci. 39:687.

Reid, J. T., A. Bensadoun, L. S. Bull, J. H. Burton, P. A. Gleeson, I. K. Han, Y. D. Joo, D. E. Johnson, W. R. McManus, O. L. Paladines, J. W. Stroud, H. F. Tyrrell, B.D.H. Van Niekerk and G. W. Wellington. 1968. Some peculiarities in the body composition of animals. In: Body Composition in Animals and Man. Proc. Symp. May 4-6, 1967, Univ. of Missouri, Columbia. Publ. 1598. pp 19-44. National Academy of Sciences, Washington, DC.

Reid, J. T., G. H. Wellington and H. O. Dunn. 1955. Some relationships among the major chemical components of the bovine body and their application to nutritional investigations. J. Dairy Sci. 38:1344.

Rudolph, B. C., T. S. Stahly and G. L. Cromwell. 1988. Estimation of body composition of neonatal pigs via deuterium oxide dilution: validation of technique. J. Anim. Sci. 66:53.

Rule, D. C., R. N. Amold, E. J. Hentges and D. C. Beitz. 1986. Evaluation of urea dilution as a technique for estimating body composition of beef steers in vivo: validation of published equations and comparison with chemical composition. J. Anim. Sci. 63:1935.

San Pietro, A. and D. Rittenberg. 1953. A study of the rate of protein synthesis in humans. I. Measurement of the urea pool and urea space. J. Biol. Chem. 201:445.

SAS. 1985. SAS User's Guide: Statistics. SAS Inst, Inc., Cary, NC.

Shebaita, M. K. 1977. Evaluation of water concept for in-vivo body composition. World Rev. Anim. Prod. 
13:65.

Shields, R. G., Jr., D. C. Mahan and F. M. Byers. 1983a. Efficacy of deuterium oxide to estimale body composition of growing swine. J. Anim Sci. 57:66.

Shields, R. G., Jr., D. C. Mahan and P. L. Graham. 1983b Changes in swine body composition from birth to $145 \mathrm{~kg}$. J. Anim. Sci. 57:43.
Stansbury, W. F., R. L. Preston, C. B. Ramsey and L. F Tribble. 1985. Urea as a body water diluent to determine body composition of swine. J. Anim. Sci. 61(Suppl. 1):302 (Abstr.).

Trenkle, A. 1986. Use of urea and deuterium oxide to measure body composition. J. Anim. Sci. 63(Suppl. 2):96. 